\title{
Design Manufacture of Fixture Fire Fighter Kit
}

\author{
Wirda Novarika ${ }^{1}$, Fatahul Arifin ${ }^{2}$, Eka Satria Martomi ${ }^{2}$, Indra Gunawan' ${ }^{2}$, Fathur Raihan Perdana ${ }^{2}$ \\ 'Departemen of Industrial Engineering, Universitas Islam Sumatera Utara, Medan, Indonesia, 20217 \\ ${ }^{2}$ Department of Mechanical Engineering, Politeknik Negeri Sriwijaya, Palembang, Indonesia, 30159
}

\begin{tabular}{|c|c|}
\hline Article Info & ABSTRACT \\
\hline Article history: & \multirow{6}{*}{$\begin{array}{l}\text { Forest fires are one that needs attention in Indonesia. Due to spent a lot of } \\
\text { money to solve this problem. One of the tools to solve this problem is fire } \\
\text { fighter, so in case is need to make the fixture can manufacture the fire fighter } \\
\text { kit. In this study, we propose the fixture that can be produce the kit. It call } \\
\text { fixture fire fighter kit. Autodesk inventor is applied in the simulation design } \\
\text { and also it is considering with the ergonomic for the worker especially the } \\
\text { Indonesian male. Finally, this tool can be resistant with load } 50 \mathrm{~kg} \text {, the } \\
\text { deflection is } 0.831 \mathrm{~mm} \text {, and the maximum von misses stress is } 34.12 \mathrm{MPa} \text {. }\end{array}$} \\
\hline Received Oct 12, 2021 & \\
\hline Revised Dec 10, 2021 & \\
\hline Accepted Dec 25, 2021 & \\
\hline Keywords: & \\
\hline \multirow{4}{*}{\multicolumn{2}{|c|}{$\begin{array}{l}\text { Fixture } \\
\text { Fire } \\
\text { Fighter } \\
\text { Ergonomic }\end{array}$}} \\
\hline & \\
\hline & \\
\hline & \\
\hline \multirow[t]{2}{*}{ Kit } & This is an open access article under the CC BY-SA license. \\
\hline & (CC) \\
\hline \multicolumn{2}{|l|}{ Corresponding Author: } \\
\hline \multicolumn{2}{|l|}{ Eka Satria Martomi, } \\
\hline \multicolumn{2}{|c|}{ Department of Mechanical Engineering, } \\
\hline \multicolumn{2}{|c|}{ Politeknik Negeri Sriwijaya, } \\
\hline \multicolumn{2}{|c|}{ Jalan Srijaya Negara Bukit Besar Palembang. } \\
\hline \multicolumn{2}{|c|}{ Email: martomi.ekasatria@gmail.com } \\
\hline
\end{tabular}

\section{INTRODUCTION}

Forest fires are one that needs attention in Indonesia. Based on data from the National Disaster Management Agency (BNPB), the total affected area reached 942,484 hectares. This number increased when compared to last year which reached 529,266 hectares in 2019. Based on data from the World Bank (World Bank), the total economic loss reached IDR 75 trillion [1].

Along with the times, people want something practical in the sense that it can save time, energy, and materials. So, in the case of forest fires where if there is a fire, access to reach the fire point is not possible for the fire engine to pass, then a tool is needed to help bring equipment to extinguish the fire point. From these problems, a tool called the "Forest Firefighter Kit" emerged, where this tool can be used to carry equipment to extinguish fires without using a car.

The fixtures are needed to assist welding of fire fighter kit in the manufacturing process.

The fixture is a tool for holding materials in order to make accurate duplicating components in mass product. The coloration alignment between the cutting tool or other aids, and the workpiece must be maintained. So, the jig or fixture is used which is designed to hold, support and position each part in welding process [2].

These fixtures can help hold the component parts to be welded and can be shifted to make changing the welding position easier. By using this tool, the difficulties of welding process can be minimized, It will be easier in the process of welding the fire extinguisher kit due to only places the parts to be welded in the fitting without having to hold the parts one by one. 
The Fixtures are an important element of the mass production process as they are required in most automated manufacturing for inspection and assembly operations with the aim of placing the workpiece into the exact position given by a cutting or measuring tool, or against another component, as for example in assembly or welding [3].

Welding in general is a process of joining metals into one due to heat with or without the influence of pressure or can also be defined as a metallurgical bond caused by attractive forces between atoms.

According to the "Welding Handbook" welding is a process of joining materials that results in the melting of materials by heating them to the right temperature with or without applying pressure and with or without the use of fillers. Welding is a metal joining process in which metals become one due to the heat of welding, with or without the influence of pressure, and with or without filler metal (Howard, 1981) [3].

We must determine the tools and components that we use in the manufacturing process. Before starting the calculation, a planner must first select and determine the type of material to be used without being separated from the factors that support it. Then, we will choose the material. Furthermore, it will be faced with calculations, namely whether the component can stand to a big force, a torsional load, a bending load, or a pressure resistance factor.

Many scholars have applied the computer application such as inventor, solid work, and so on to calculate the manufacturing process. Wang et.al applied the Moldex to calculate the molding process of the blu ray lens and LED [4-6]. Arifin et.al used Inventor to determine the von mises stress, deflection and safety factors in the designing vise with the $45^{\circ}$ angle [7]. Kamal et.al and Irawan et.al examined the strength of wind turbine using solid work software [8] [9]. Then, Germana et.al. studied the combination Savonius and Darrius wind turbine by applying the solid work software [10].

Besides that, in the designing and manufacturing of this fixture, it can't be separated from ergonomics aspect (convenience for workers to use this tools).

The purpose of this study to get the best designing the fixtures that is able to solve the problem in manufacturing process of firefighter kit.

\section{RESEARCH METHOD}

The method used in the design of fixture for fire fighter kit is an analytical method to analyze the strength of the design results by calculation and using software, while to analyze and identify possible failures in the process, function and product design so that it is known The cause and effect of increasing the resistance of the designed tool is FMEA (Failure Mode Effect Analysis [11].

The research begins by collecting the required information about the gripping aids, especially in construction design. Information is collected from various sources, such as the internet, literature, and field research. Then do the 3-dimensional modeling of the design to then analyze the strength of the frame construction and the overall circuit calculation and using software.

The following is a flowchart of the design and construction of welding fittings for the production of fire fighter kit (Figure 1).

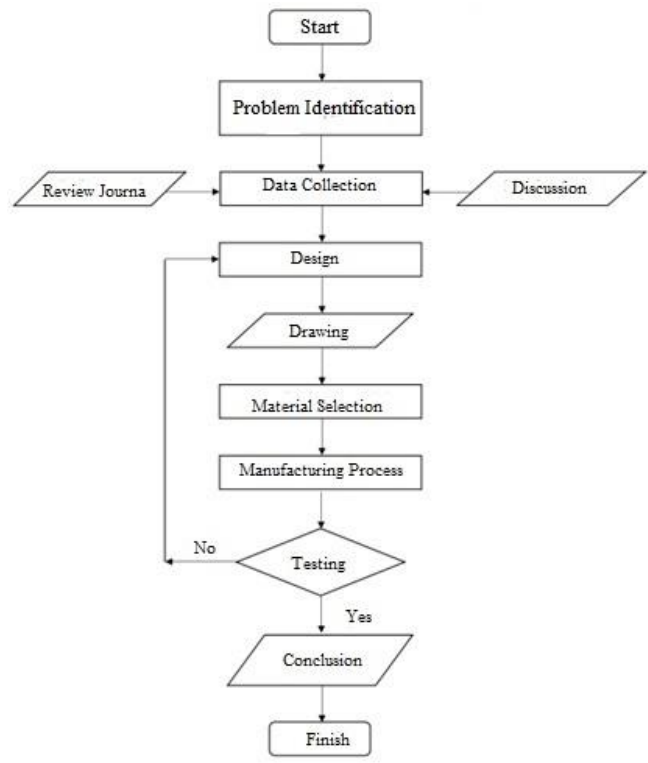

Figure 1. Research flow chart 


\subsection{Ergonomic Factor}

Indonesians are an average $158.17 \mathrm{~cm}$ tall. Indonesian men are $163.55 \mathrm{~cm}$ tall on average. Indonesian women are $152.79 \mathrm{~cm}$ tall on average and hand length $75 \mathrm{~cm}$. So, the design of fixture for fire fighter kit should consider these factors [12-13].

\subsection{Analysis Load Welding Calculation}

The welded part will receive the greatest load which is located on the table frame. Therefore, theoretically it can be calculated using the following formula [14]:

Weld Cross-sectional Area

$$
\mathrm{A}=2 \times \frac{t \times l}{\sqrt{2}}
$$

Shear stress

Shear stress permission

$$
\tau_{\mathrm{g}}=\frac{F}{A}
$$

$$
\begin{gathered}
\sigma_{\mathrm{t}(\mathrm{i})}=\frac{\sigma_{t}}{s f} \\
\tau_{\mathrm{g}(\mathrm{i})}=\frac{\sigma t_{(i)}}{2}
\end{gathered}
$$

Welding Length

Welding Thickness

$$
\mathrm{L}=2 \times 1
$$

$$
\mathrm{t}=\sin 45^{\circ} \times \mathrm{s}
$$

Welding Stress

$$
\mathrm{P}=\mathrm{A} \times \tau_{\mathrm{g}(\mathrm{i})}
$$

\subsection{Analysis Calculation Based on Simulation}

The simulation is done using Autodesk Inventor software. The simulation analysis carried out is a static load analysis or stress analysis, namely by making a 2D and 3D frame model, verifying the material or filling in the material properties table (Table 1), determining the constraints, gravity, given load, so that the results are taken into consideration. for the construction of a planned tool (Figure 2a) or product (Figure 2b).

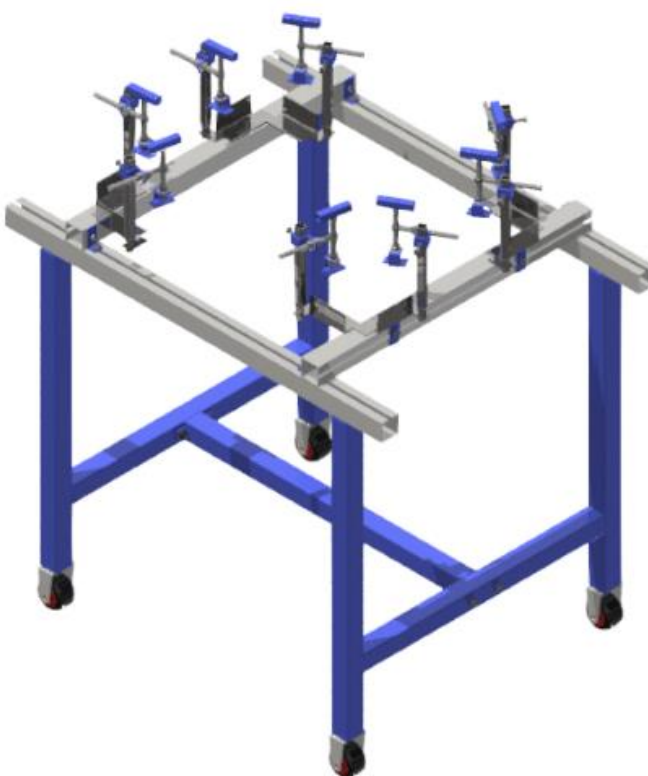

a.

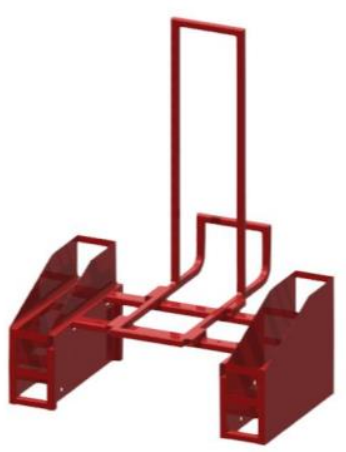

b.

Figure 2. a) Welding Fixture for Making Firefighter Kit; b) Firefighter Kit Product 
Table 1. Material Properties

\begin{tabular}{lll}
\hline \multicolumn{1}{c}{ Name } & \multicolumn{1}{c}{ Number } \\
\hline \multirow{3}{*}{ General } & Mass Density & $0.894 \mathrm{~g} / \mathrm{cm}^{\wedge} 3$ \\
& Yield Strength & $10.8 \mathrm{MPa}$ \\
& Ultimate Tensile Strength & $11 \mathrm{MPa}$ \\
& Young's Modulus & $0.124 \mathrm{GPa}$ \\
Stress & Poisson's Ratio & $0.41 \mathrm{ul}$ \\
& Shear Modulus & $0.0439716 \mathrm{GPa}$ \\
\hline
\end{tabular}

This simulation is carried out on the whole assembly with different forces or loads, from $10 \mathrm{~kg}$ to 50 $\mathrm{kg}$ with an interval of $10 \mathrm{~kg}$ (it is assumed that the compressive force during the machining process that will occur is $1 \mathrm{~N}$ to $5 \mathrm{~N}$ and gravity is $9.8 \mathrm{~m} / \mathrm{s} 2$ ) to determine the level of resistance of each construction.

\section{RESULTS AND DISCUSSION}

\subsection{The Ergonomic Design}

The design construction of the fixture for fire fighter kit consider with the ergonomic factor can be seen in figure 3 .

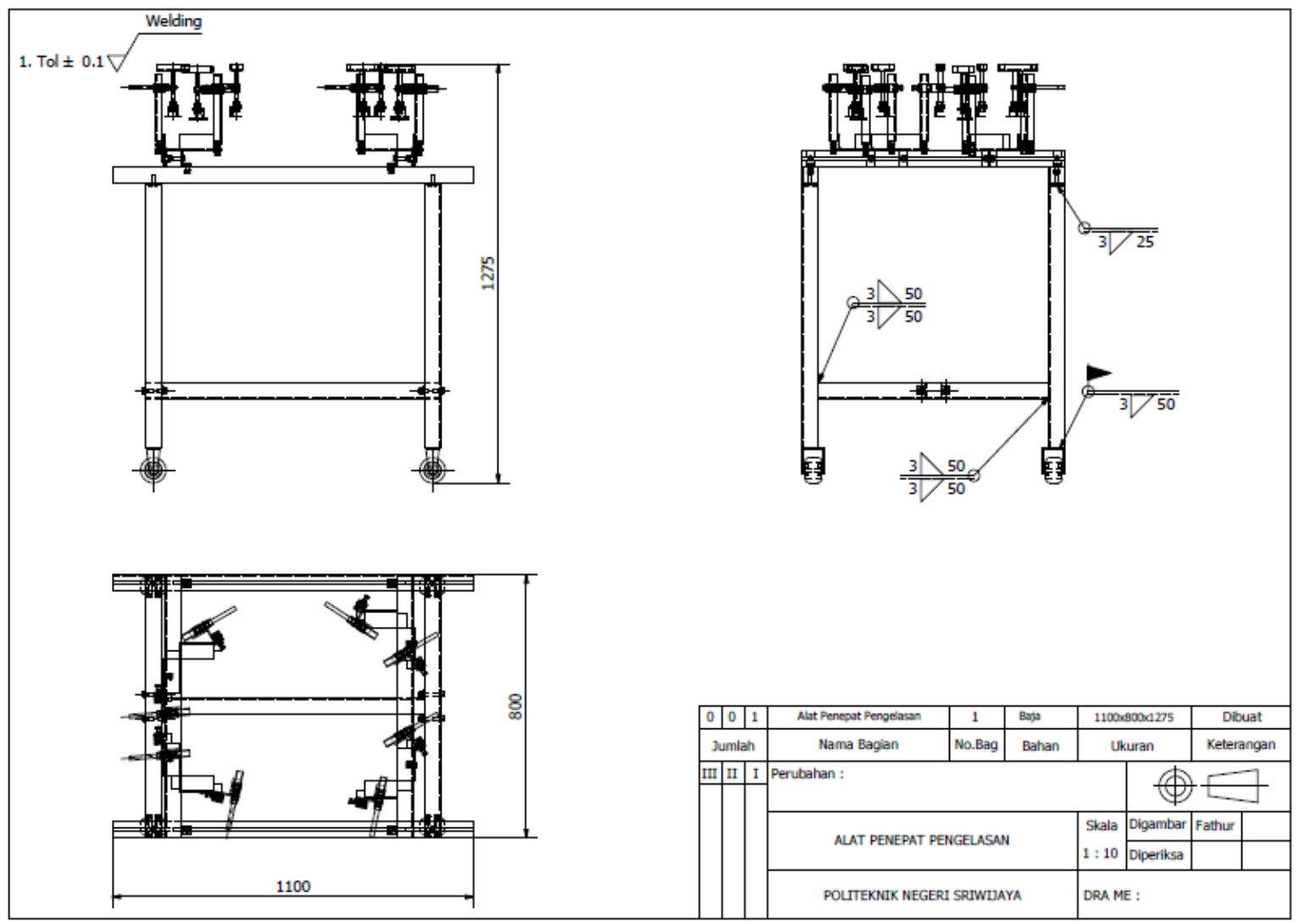

Figure 3. Technical Drawing Fixture for Making Firefighter Kit

\subsection{Analysis Load Theories}

Welding that receives the greatest load is located on the table frame. The load that must be accepted is $\mathrm{F}=212,621 \mathrm{~N}$. Welding carried out in this section is SMAW welding with the type of T-joint angle welding connection. The electrode used is E6013 $2.0 \mathrm{~mm}$. calculation of the weld strength at the bottom of the frame connection, namely hollow iron $50 \times 50 \times 2 \mathrm{~mm}$. 
- Weld Cross-sectional Area

$$
\begin{aligned}
\text { A } \quad & =2 \times \frac{t x l}{\sqrt{2}} \\
& =2,121 \times 50 \mathrm{~mm} \times 2 \mathrm{~mm} \\
& =212,1 \mathrm{~mm}^{2} \times 4 \\
& =\mathbf{8 4 8 , 4} \mathbf{m m}^{2}
\end{aligned}
$$

- Shear stress

$$
\tau_{\mathrm{g}} \quad=\frac{F}{A}
$$

$$
\begin{aligned}
& =\frac{170,74 \mathrm{~N}}{848,4 \mathrm{~mm} 2} \\
& =\mathbf{0 , 2 0 1 ~} \mathbf{N} / \mathbf{m m}^{2}
\end{aligned}
$$

- Shear stress permission

The hollow steel that is used has a tensile strength $(\sigma t)$ of $370 \mathrm{~N} / \mathrm{mm}^{2}$ or ST37.

$$
\begin{aligned}
& \sigma_{\mathrm{t} \text { ijin }}=\frac{\sigma_{t}}{s f} \\
& =\frac{370 \mathrm{~N} / \mathrm{mm}^{2}}{4} \\
& =92,5 \mathrm{~N} / \mathrm{mm}^{2} \\
& \tau_{\mathrm{g} \text { ijin }}=\frac{\sigma t_{i j i n}}{2} \\
& =\frac{92,5 \mathrm{~N} / \mathrm{mm}^{2}}{2} \\
& =46,25 \mathrm{~N} / \mathrm{mm}^{2}
\end{aligned}
$$

- Welding Length

$\mathrm{L}=2 \times 1$

$$
\begin{aligned}
& =2 \times 50 \mathrm{~mm} \\
& =100 \mathrm{~mm} \mathrm{x} 4 \\
& =\mathbf{4 0 0} \mathbf{~} \mathbf{m m}
\end{aligned}
$$

- Welding Thickness

$\mathrm{t} \quad=\sin 45^{\circ} \times \mathrm{s}$

$$
=0,707 \times 3 \mathrm{~mm}
$$$$
=2,121 \mathrm{~mm}
$$

- Welding Stress

$$
\begin{aligned}
\mathrm{P} & =\mathrm{A} \times \tau_{\mathrm{g} \text { iji }} \\
& =848,4 \mathrm{~mm}^{2} \times 46,25 \mathrm{~N} / \mathrm{mm}^{2} \\
& =\mathbf{3 9 . 2 3 8 , 5} \mathbf{N}
\end{aligned}
$$

Because $\mathrm{F}<\mathrm{P}$, the welding of the frame with the $\mathrm{E} 6013$ electrode on the hollow iron frame is safe to withstand a load of 212,621 N.

\subsection{Analysis Load Simulation}

\subsubsection{Static Load Result}

The 3D fixture fire fighter kit design (Figure 4) applies the Autodesk inventor software can be seen in the image below: 


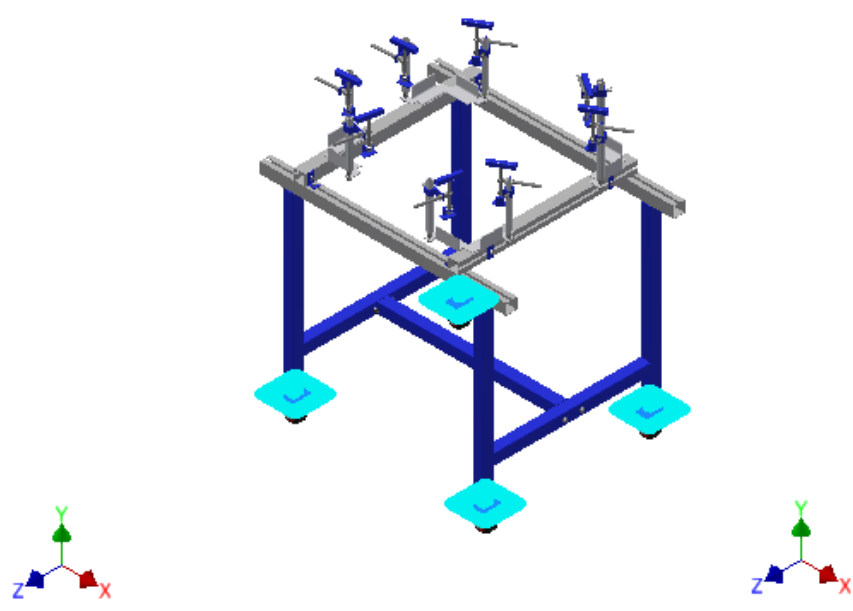

a.

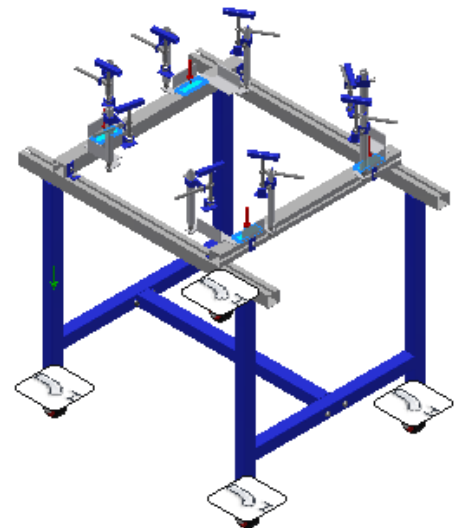

b.

Figure 4 a) Force Position b) Fixed Constraint, Pin Constraint and Friction Constraint

Determining the constraint (Figure 4a) is done by referring to the position of the pedestal on the design product that has been modeled. Constraints can be fixed constraints, pin constraints, and friction constraints. While the load in this analysis is made to vary from $10 \mathrm{~kg}, 20 \mathrm{~kg}, 30 \mathrm{~kg}, 40 \mathrm{~kg}$ and $50 \mathrm{~kg}$. The gravity value used is $9.8 \mathrm{~m} / \mathrm{s} 2$ so that the force values obtained are $98 \mathrm{~N}, 196 \mathrm{~N}, 294 \mathrm{~N}, 392 \mathrm{~N}, 490 \mathrm{~N}$ which are tested on the construction of the tool. The following is a picture of the constraints and loading at a maximum load of 50 $\mathrm{kg}$, which is $490 \mathrm{~N}$. The force is positioned in the two upper planes of the frame to determine the strength of the frame to withstand the load in that position, while in (Figure 4b) the force is positioned in the middle of the tool construction plate component to obtain uniform construction strength analysis results. The yellow arrow is a symbol of the force or load while the purple color is the direction of the earth's gravity.

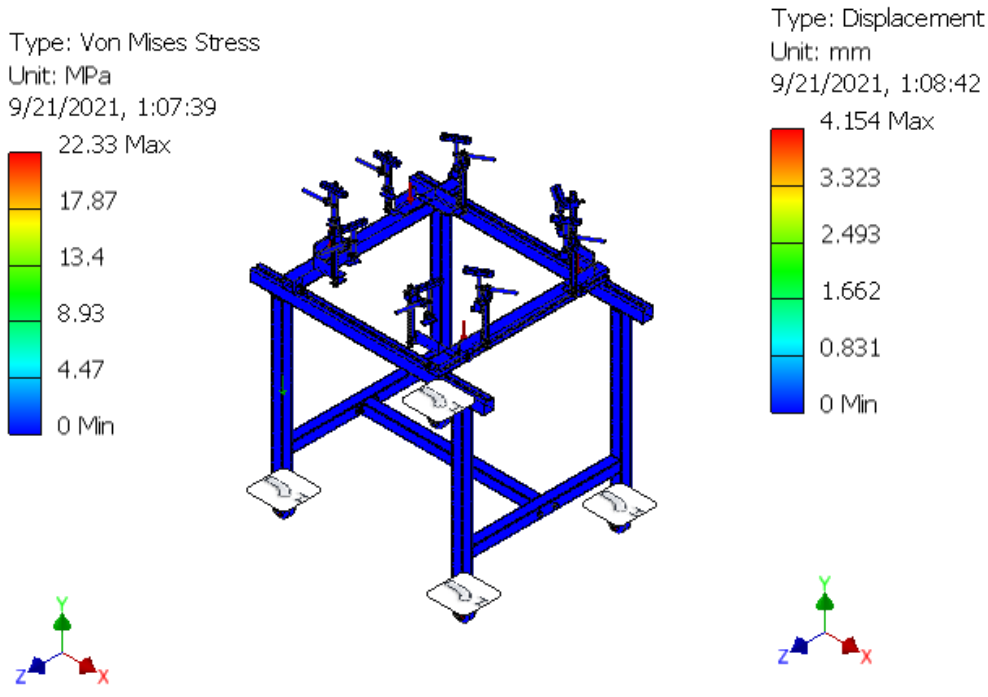

a.

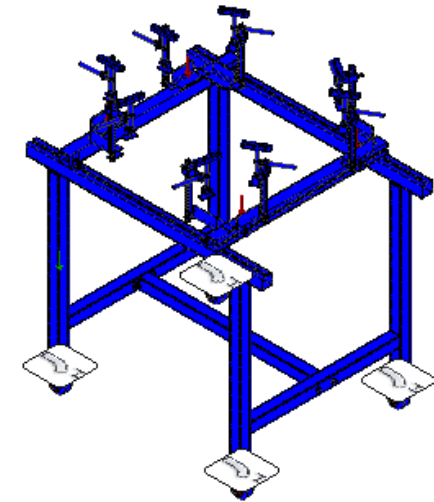

b. 
Type: Safety Factor

Unit: ul

$9 / 21 / 2021,1: 08: 26$
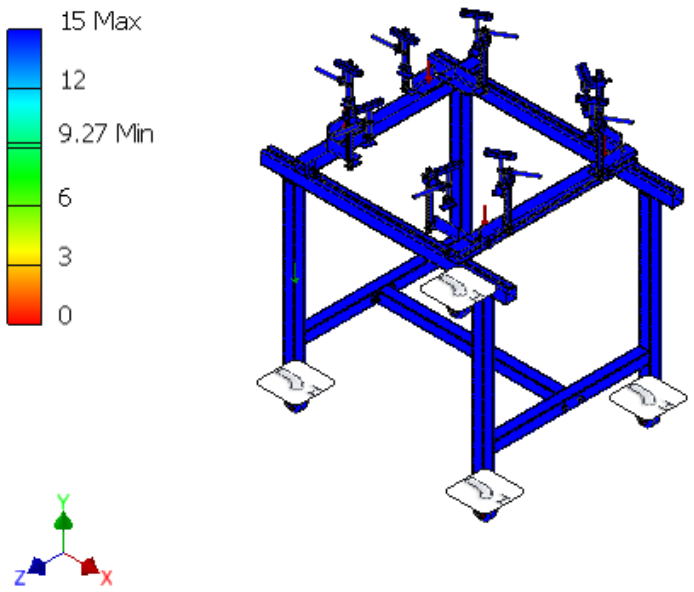

c.

Figure 5. Result of Simulation a) Von Mises Stress b) Displacement c) Safety Factor

\subsubsection{Results Static Load Recapitulation}

After run several experiments that have been carried out, the results of the data are considered in the construction of the tool are as can be seen in Table 2 .

Table 2. Results Static Load Recapitulation

\begin{tabular}{cccc}
\hline Force & Von Misses Stress (MPa) & $\begin{array}{c}\text { Simulation Results } \\
\text { Deflection (mm) }\end{array}$ & Safety Factor \\
& 22.33 & 0.831 & 9.27 \\
$20 \mathrm{~kg}$ & 25.27 & 0.831 & 8.19 \\
$30 \mathrm{~kg}$ & 28.22 & 0.831 & 7.36 \\
$40 \mathrm{~kg}$ & 31.24 & 0.831 & 6.63 \\
$50 \mathrm{~kg}$ & 34.12 & 0.831 & 6.07 \\
\hline
\end{tabular}

In Figure 4 and table 2, it can be seen that for a maximum load of $50 \mathrm{~kg}$, the area on the frame of this clamp is still blue, so it is confirmed that this tool is able to withstand the maximum load, and the maximum deflection that occurs is very small $0.831 \mathrm{~mm}$ and has a different where factor. 6.07 high. So from this simulation analysis, the designed tool will be safe for a load of $50 \mathrm{~kg}$.

\section{CONCLUSION}

The construction of Fixture of fire fighter kit maker has adjusted the ergonomics of the comfort of the workers who wear this tools, and it is also included in the group that is resistant to static loads whose minimum safety factor is 6.07 , so that the frame is still safe to accept a load of $50 \mathrm{~kg}$ with the position of placing the force on the upper plane of the frame. Due to the safety factor is above the minimum required for the static load.

The maximum deflection occurs in the frame in the upper frame is $0.831 \mathrm{~mm}$, with a load of $50 \mathrm{~kg}$. It mean, the design is safe against a force of $50 \mathrm{~kg}$.

The maximum Von Misses stress that occurs in the frame at the top of the frame connection with a load of $50 \mathrm{~kg}$. Then, it is not seen in the simulation analysis, so it can be assumed that this fixture is safe for that $50 \mathrm{~kg}$ maximum load. 


\section{REFERENCES}

[1] Website "Kerugian Kebakaran Hutan dan Lahan Sepanjang 2019 Capai Rp 75 Triliun", https://bnpb.go.id/berita/kerugian-kebakaran-hutan-dan-lahan-sepanjang-2019-capai-rp-75-triliun., retrieved on October 10, 2021.

[2] K. Venkatarama., "Design of Jigs, Fixtures and Press Tools", John Wiley \& Sons Ltd, West Sussex, United Kingdom, 2015

[3] E. Hady, , "Jig and Fixture" https:// www.kompasiana.com/1991/55008c1aa3331130725112d6/jig-danfixture, retrieved on October 10, 2020

[4] M. W. Wang, C. H. Chen, F. Arifin, and J.J Lin, "Modeling and analysis of multi-shot injection molding of Blu-ray objective lens", Journal of Mechanical Science and Technology vol. 32 ed.10 hal. 4839 4849, DOI 10.1007/s12206-018-0932-z, Jun. 2018

[5] M. W Wang., F.Arifin, J. Y. Huang. "Optimization of The Micro Molding of A Biconcave Structure. International Journal of Technology" 10(2): 269-279. 2019

[6] M. W Wang., F.Arifin, H. L. Kuo ,"Study on micromoulding of a high viewing angle LED lens". Plastics, Rubber and Composites, DOI: 10.1080/14658011.2019.1685803, 2019

[7] F. Arifin, D. Arnoldi, E. Sundari, F. Putri, F. Agasa, Y. Ramadhan, G. Susetyo, Y. D, Herlambang, "Study of strength analysis simulation of Jig and Fixture 45 degree bore", Jurnal Polimesin. Vol. 18, No. 2, DOI: http://dx.doi.org/10.30811/jpl.v18i2.1837, 2020

[8] M Kamal, F. Arifin, Rusdianasari, "Analysis of the Performance of The Four-Blade Darrieus Wind Turbine at the Jamik Bukit Asam Mosque Complex Tanjung Enim South Sumatra", International Journal of Research in Vocational Studies (IJRVOCAS), Print ISSN 2777-0168, Online ISSN 2777-0141, DOI: https://doi.org/10.53893/ijrvocas.v1i2.52

[9] O. Irawan, Y. Bow, R.D. Kusumanto,"Simulation and Performance Test Giromill Type Wind Turbine; Case Study Muara Enim, South Sumatra, Indonesia ", International Journal of Research in Vocational Studies (IJRVOCAS), Print ISSN 2777-0168, Online ISSN 2777-0141, DOI: DOI: https://doi.org/10.53893/ijrvocas.v1i2.10

[10] A. Garmana, F. Arifin, Rusdianasari, "CFD Analysis for Combination Darrieus and Savonius Turbine with Differences in the Number of Savonius Turbine Blades," International Conference on Artificial Intelligence and Mechatronics Systems (AIMS), 2021.

[11] Hasbullah, H., Kholil, M., Santoso, D. A., "Analisis Kegagalan Proses Insulasi Pada Produksi Automotive Wires (AW) Dengan Metode Failure Mode and Effect Analysis (FMEA) Pada PT JIC", Jurnal Sinergi Vol. 21, No.3, hal. 193-203, DOI:doi.org/10.22441/sinergi.2017.3.006, 2017

[12] Website "What is the average hand size?", https://www.medicalnewstoday.com/articles/average-handsize\#adults retrieved October, 26, 2021

[13] Website "Ranked: The countries with the shortest people in the world", https://www.insider.com/shortestpeople-in-world-by-country-2019-6\#12-malawi-15831cm-5-feet-232-inches-14 retrieved October, 26, 2021

[14] Website "Welding Calculator", https://www.omnicalculator.com/construction/welding retrieved October, 10,2020 


\section{BIOGRAPHIES OF AUTHORS}
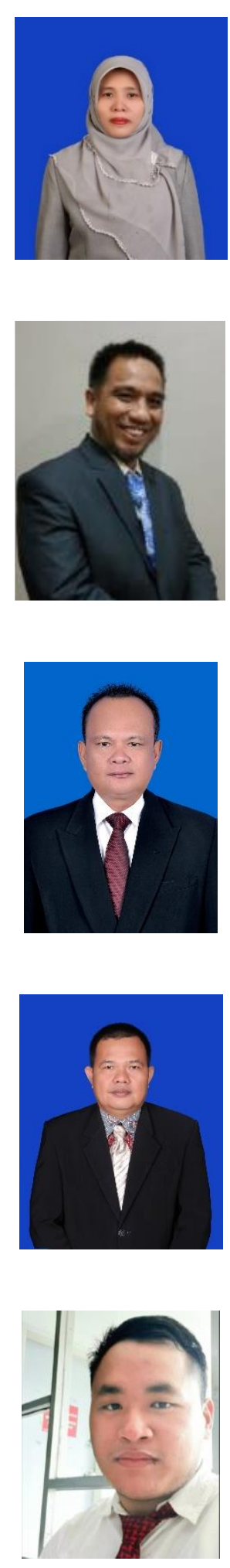

Wirda Novarika AK was born in Palembang, South Sumatera, Indonesia. She is Lecture in Industrial Engineering Department, Engineering Faculty, Universitas Islam Sumatera Utara, Indonesia. She is interested in product design, production management and industrial manufacture process.

Dr. Phil. Fatahul Arifin, S.T., Dipl., Eng., EPD., MEngSc. is a Lecturer in Mechanical Engineering Department, Politeknik Negeri Sriwijaya and also teach in Magister of Renewable Energy Department Politeknik Negeri Sriwijaya. He is interested in renewable energy application, manufacturing, and product design. Many arcticles have written by him in conference and international journal.

Eka Satria Martomi, B.Eng., Dipl., Eng., EPD., MT, is a Lecturer in Mechanical Engineering Department, Politeknik Negeri Sriwijaya He is interested in material science, manufacturing, and product design. Many arcticles have written by him in conference and international journal

Indra Gunawan, ST., MSi is a Lecturer in Mechanical Engineering Department, Politeknik Negeri Sriwijaya He is interested in product engineering process, manufacturing, and machine contruction. Some arcticles have written by him in conference and international journal

Fathur Raihan Perdana is alumni D3 in Mechanical Engineering Department, Politeknik Negeri Sriwijaya He is interested in product engineering process, manufacturing, and machine contruction. He is doing PTBA project in Tanjung Enim. 